\title{
Alzheimer Research Forum Report: Tübingen: The Man Behind the Eponym
}

\author{
Gabrielle Strobel \\ Alzheimer Research Forum
}

16 November 2006. Everyone with even a passing interest in Alzheimer disease has seen a sepia-toned photograph of its namesake like the one on last week's cover of Science magazine. A fatherly, pensive man with a mustache, sometimes a cigar, photographed from his right side and often with hands folded in his lap as was customary for sitting portraits at the time. But there is much more to Alois Alzheimer, and participants at the Alzheimer 100 Centennial conference, held 3-6 November in Tübingen (where Alzheimer studied for a semester), were treated to a glimpse or two.

Conference co-organizer Konrad Maurer directs the Clinic for Psychiatry and Psychotherapy at the Johann Wolfgang Goethe University of Frankfurt, where Alzheimer worked when he met his patient Auguste Deter. Maurer and his wife Ulrike are a fountain of knowledge about the man, his work, and his time. They took conventioneers on a tour to the house in the Bavarian town of Marktbreit at the river Main, where Alzheimer was born on 14 June 1864 as one of eight children to a notary at the royal regional court. (When Alzheimer's older brother Karl was born, Karl's mother died. Alzheimer's father waited the year that social custom required before he married her twin sister. Karl and Alois indeed look so alike that on some photographs it's nearly impossible to tell them apart, were it not for a scar on the left cheek that Alois sustained during a fencing duel in his student fraternity.) Ulrike Maurer restored Alois' birth house as a museum in the style of Alzheimer's time. The notes below are taken from the tour and from Alois Alzheimer, His Life and Work with Text and Photographs [1].

Alzheimer disease has become one of the most widely known eponyms for any human illness. One might think that the man behind it focused on it exclusively throughout his career. But that's far from true. Alzheimer worked on an astonishing range of diseases of the mind, and published equally widely. He was deeply tied into clinical service at his successive places of work in the cities of Frankfurt, Heidelberg, Munich, and Breslau; part of his distinction lies in the fact that, in addition to his load as a hands-on physician and administrator, he studied everything that caught his interest. A dissertation, completed in Wuerzburg, on the topic of ceruminal glands (better known as the source of earwax), got him started in histology and microscopy, but the topic could not hold his curiosity. His first position as assistant physician brought him to the Lunatic Asylum of Frankfurt, an institution directed years earlier by Heinrich Hoffman, the author of the children's book Struwwelpeter. In the grandiose, fairy-tale building that housed the asylum, Alzheimer worked under Emil Sioli, who would later ship Auguste D.'s brain to Alzheimer in Munich, and with Franz Nissl, who became a close collaborator and friend.

Alzheimer and Nissl studied autopsy tissue of hundreds of different psychiatric cases. Even then, they both believed that mental diseases are brain diseases, and that organic, that is, anatomic/pathologic correlates could be found that would allow a much more specific classification than existed at the time. Alzheimer also was convinced that the symptoms he saw in his patients represented a far greater number of distinct mental illnesses than the current categories suggested. His time in Frankfurt, from 1888 to 1903, was prolific. He published 23 papers, on topics ranging from arteriosclerotic atrophy of the brain (Alzheimer believed that arteriosclerosis caused what is now considered the late- 
onset form of AD), to what was then called progressive paralysis. He published on alcoholic delirium, meningoencephalitis, epilepsy, and gliosis. Even then, he tried to grasp an anatomic and pathologic basis of psychosis, a challenge that would confound pathologists for decades to come.

Alzheimer also brought his perspective to his work as a forensic psychiatrist. One vignette that shows how modern he was is his early behavioral psychology experimentation with a shoe fetishist. The man became aroused at the sight of ladies' footwear and, according to Konrad Maurer, had been picked up in a hotel, where guests used to leave their shoes in the corridor overnight for cleaning. Alzheimer arranged to have a women's shoe placed discretely near the man, observed him as he became restless, and meticulously noted his mood (somber that evening) and his pulse (elevated from the usual 85 to 125 per minute).

While in Frankfurt, Alzheimer treated a wealthy diamond merchant who in 1892 died from progressive paralysis. This type of diagnosis was common at the time. A few years later it would prove to be a consequence of syphilis and became a signature example for an infectious origin of mental illness. In 1894, Alzheimer married the merchant's widow, Cecilie Geisenheimer. The marriage appears to have been happy and produced three children. Unlike some others who become independently wealthy, Alzheimer did not slow down in his work at all. On the contrary, he used his independence to focus freely on his research, and indeed decided to forgo a salary in his later job in $\mathrm{Mu}-$ nich and to pay some of his lab members out of his own pocket. Without this independence, the Maurers' book notes, he might not have been able to prevail against the current of psychoanalytic thinking in his time.

On 25 November 1901, a 51-year old Frankfurt resident entered the lunatic asylum, and Alzheimer himself wrote her admission papers. The Maurers' biography reprints four neatly handwritten pages in which Alzheimer carefully documented his examination of this women, Auguste Deter. On 23 December 1995, Konrad Maurer had found her case file containing the original admission and eventual pathology documents at the University of Frankfurt, where they had been misplaced for decades. The admission papers reveal Alzheimer's gentle probing of her various cognitive domains. They record her disturbed behavior (hitting other patients, screaming), as well as conversations that reveal her memory loss, confusion, and her despair. Auguste's husband told Alzheimer that she first became suspicious and jealous of a neighbor. (According to
Maurer, the husband married this neighbor a year after Auguste's death.) Alzheimer added to her file until June 1902. When she died on 8 April 1906 from sepsis following bedsores, Alzheimer had long since moved briefly to Heidelberg and then on to Munich. He became highly regarded for his research on alcohol addition and his approach to alcoholism therapy, and explored many other conditions as well. It is remarkable, then, how amid all these changes and distractions, Alzheimer maintained his interest in this particular woman and had her brain sent so he could examine it. After he had analyzed Auguste D.'s brain, the original slides disappeared, only to resurface, decades later in 1997, in a Munich university basement.

In Munich, Alzheimer worked with Kraepelin, the foremost German psychiatrist of his time. There, Alzheimer obtained his habilitation, an obligatory final step of academic qualification in Germany, with a thesis on the histologic analysis of cortical pathology in 320 separate cases of mental disorders, all of which he dissected, prepared, and drew himself. Kraepelin wrote about this work that Alzheimer proved pathological anatomy to be an indispensable tool for research of mental disorders, and that his work excelled in how it maintained a close relationship between anatomy and clinical observation. In Munich, Alzheimer stood out for his international group, hiring scientists from all over Europe and from the U.S. and Argentina. He mentored investigators who would become known in their own right, including Hans-Gerhard Creutzfeldt and Alfons Jakob, F. H. Lewy, and Gaetano Perusini. He was known as warmhearted, unassuming, available to his students and protégées, but a poor lecturer.

In Munich, Alzheimer published 31 papers. They include not only his most famous one describing Auguste D. [2], but also a paper in 1911 on his second patient, Johann F. This case may have prompted Kraepelin, in a psychiatry textbook he published in 1909, to coin the term "Alzheimer disease" for what Alzheimer and his colleagues had until then called presenile dementia, writes Hans Kluenemann, who has tracked Johann F.'s pedigree [3]. Ironically, Johann F.'s case does not fit the classic pathologic definition of Alzheimer disease, since he had only amyloid plaques, no tangles. By 1909, Alzheimer and Perusini had published their analysis of five AD patients.

During this period, too, Alzheimer published widely, from reports on Wallerian degeneration of peripheral nerves and on Huntington disease to controversial societal issues such as abortion in mentally ill people. He was ahead of his time in many ways. He defended 
the interests of mentally handicapped people. He argued that a biology-based characterization of mental illnesses would become possible once the structure of the normal cortex was better known, and that the current absence of evidence was not evidence of absence. And he contributed to a public debate that led, eventually, to the founding of the Max-Planck Institute of Psychiatry in Munich.

In 1912 Alzheimer moved to the Silesian FriedrichWilhelm University in Breslau, but on his way there fell sick with an infectious angina from which he never fully recovered. He produced 19 more scientific papers in the next three years. Notable among them is one titled "War and Nerves." Published a year after the First World War had begun, it described what would later be called post-traumatic stress disorder. On 15 December 1915, Alois Alzheimer died at the age of 51. He was buried next to his wife in Frankfurt.
Previously published at http://www.alzforum.org /new/detail.asp?id=1481.

\section{References}

[1] K. Maurer and U. Maurer, Alois Alzheimer, His Life and Work with Text and Photographs. Pre Press Print Production Service, Marburg, 2002, ISBN 3-935966-05-09.

[2] A. Alzheimer, Über eine eigenartige Erkrankung der Hirnrinde, Allgemeine Zeitschrift fur Psychiatrie und Psychischgerichtliche Medizin 64 (1907), 146-148.

[3] H.H. Klünemann, W. Fronhöfer, H. Wurster, W. Fischer, B. Ibach and H.E. Klein, Alzheimer's second patient: Johann F. and his family, Ann Neurol 52 (2002), 520-523. 